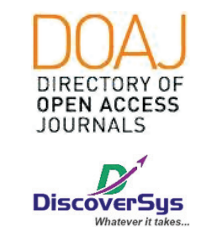

Published by DiscoverSys

\title{
Proporsi gangguan tidur pada mahasiswa program studi pendidikan dokter semester satu dan semester tujuh Fakultas Kedokteran Universitas Udayana, Bali, Indonesia
}

\author{
I Nyoman Andika Kumara, ${ }^{1 *}$ Luh Nyoman Alit Aryani, ${ }^{2}$ Ni Ketut Sri Diniari ${ }^{2}$
}

\section{ABSTRACT}

Background: Higher education changes status from student into college-student. In Indonesia, it is regarded more than just student, which make college student have more higher demands. Academic demands they face become their stressor. And this stressor itself can trigger sleep disturbance, especially in medical students.

Objective: This research was aimed to determine the proportion of sleep disturbance among medical students in the first and seventh semester at the Medical Faculty of Udayana University.

Methods: A cross-sectional descriptive study was conducted to know the proportion of sleep disturbance among medical students in first and seventh semester at Medical Faculty of Udayana University, as much as 140 college students used as samples and chosen by stratified random sampling method and using Pittsburgh Sleep Quality Index (PSQI) as an instrument for sleep disturbance measurement. Data were analyzed using SPSS version 17 for Windows.

Results: The results of the study found that 81 students experience sleep disturbance, and found more in student in the first semester at about $33,5 \%$ than in seventh semester student which only approximately $24,2 \%$. Other results based on ages and sex concluded students with the age of 18 experience sleep disturbance the most and dominantly by female students.

Conclusion: Most first semester students experience sleep disorders where the highest rate is at the age of 18 years and female sex

Keywords: Sleep disturbances, medical student, semester, age, sex

Cite This Article: Kumara, I.N.A., Aryani, L.N.A., Diniari, N.K.S. 2019. Proporsi gangguan tidur pada mahasiswa program studi pendidikan dokter semester satu dan semester tujuh Fakultas Kedokteran Universitas Udayana, Bali, Indonesia. Intisari Sains Medis 10(2): 235-239. D0I: 10.15562/ ism.v10i2.391

\section{ABSTRAK}

Latar Belakang: Pendidikan tinggi merubah status, dari siswa menjadi mahasiswa. Status ini di Indonesia dipandang lebih daripada siswa sehingga tuntutan terhadap mahasiswa menjadi lebih tinggi. Tuntutan akademik yang dihadapi mahasiswa menjadi stresor bagi mahasiswa itu sendiri. Hal-hal inilah yang mampu memicu terjadinya gangguan tidur termasuk pada mahasiswa kedokteran.

Tujuan: Penelitian ini bertujuan untuk mengetahui proporsi gangguan tidur pada mahasiswa program studi pendidikan dokter semester satu dan semester tujuh Fakultas Kedokteran Universitas Udayana.

Metode: Penelitian ini adalah suatu penelitian cross sectional deskriptif untuk mengetahui proporsi gangguan tidur pada mahasiswa program studi pendidikan dokter semester satu dan semester tujuh Fakultas Kedokteran Universitas Udayana, sebanyak 140 mahasiswa digunakan sebagai sampel yang dipilih menggunakan metode stratified random sampling dan menggunakan Pittsburgh Sleep Quality Index (PSQI) sebagai instrumen pengukuran gangguan tidur. Data di analisis menggunakan piranti lunak SPSS versi 17 untuk Windows.

Hasil: Hasil dari penelitian menemukan bahwa sebanyak 81 orang mahasiswa mengalami gangguan tidur, dan lebih banyak ditemukan pada mahasiswa semester satu yaitu sebesar 33,5\% dibandingkan dengan mahasiswa semester tujuh yaitu sebesar $24,2 \%$. Hasil yang lain berdasarkan umur dan jenis kelamin ditemukan bahwa rentang usia 18 tahun mengalami gangguan tidur paling tinggi serta gangguan tidur pada mahasiswa didominasi oleh jenis kelamin perempuan.

Kesimpulan: Sebagian besar mahasiswa semester satu mengalami gangguan tidur dimana angka tertinggi pada usia 18 tahun dan jenis kelamin perempuan
I Nyoman Andika Kumara; Program Studi Pendidikan Dokter Umum, Fakultas Kedokteran, Universitas Udayana, Bali, Indonesia andika.kumara@yahoo.com

Diterima: 25-12-2018 Disetujui: 24-05-2019 Diterbitkan: 01-08-2019
Kata kunci: Gangguan tidur, mahasiswa kedokteran, semester, umur, jenis kelamin Cite Pasal Ini: Kumara, I.N.A., Aryani, L.N.A., Diniari, N.K.S. 2019. Proporsi gangguan tidur pada mahasiswa program studi pendidikan dokter semester satu dan semester tujuh Fakultas Kedokteran Universitas Udayana, Bali, Indonesia. Intisari Sains Medis 10(2): 235-239. D0I: 10.15562/ ism.v10i2.391 


\section{PENDAHULUAN}

Pendidikan tinggi merubah status, dari siswa menjadi mahasiswa. Status ini di Indonesia dipandang lebih daripada siswa sehingga tuntutan terhadap mahasiswa menjadi lebih tinggi. Begitu pula yang diungkapkan oleh Bertens D yang menyatakan bahwa mahasiswa merupakan individu yang bersekolah di perguruan tinggi dalam kurun waktu tertentu dan memiliki tugas untuk berusaha keras dalam studinya. ${ }^{1}$ Persepsi masyarakat terhadap mahasiswa dan periode yang dijalaninya menyebabkan mahasiswa memiliki berbagai tuntutan akademik. $^{2}$

Tuntutan akademik yang dihadapi mahasiswa menjadi stresor bagi mahasiswa itu sendiri. Stresor ini berasal dari dalam diri mahasiswa maupun dari luar diri mahasiswa. Lubis-Nurlaila dan Robotham mengatakan bahwa dalam menyelesaikan akademiknya, mahasiswa dihadapkan dengan kondisi adaptasi terhadap perubahan kehidupan perkuliahan, kondisi ujian, kondisi perbedaan bahasa yang digunakan serta masalah biaya perkuliahan., Hal tersebut dialami oleh mahasiswa kedokteran, dimana menurut standar pendidikan profesi dokter, tahapan pendidikan pada program studi pendidikan dokter terdiri atas dua tahap, yaitu tahap sarjana kedokteran (tahap preklinik) dan tahap profesi dokter (tahap klinik). Di akhir masa studinya, para mahasiswa kedokteran di Indonesia pun harus mengikuti Ujian Kompetensi Mahasiswa Program Profesi Dokter (UKMPPD) agar dapat dinyatakan lulus dan mendapatkan gelar profesi dokter. Hal-hal inilah yang mampu memicu terjadinya gangguan tidur pada mahasiswa kedokteran. ${ }^{2}$

Sebuah studi menunjukkan bahwa hampir 50\% dari mahasiswa kedokteran mengalami suatu fenomena burnout atau yang lebih dikenal dengan keletihan fisik, mental dan emosional yang diikuti dengan kecemasan dan depresi terhadap suatu stresor. Beberapa stresor yang nyata dialami oleh mahasiswa kedokteran seperti jadwal kuliah yang padat, tugas yang menumpuk, rasa cemas menjelang ujian akhir dan kompetisi sesama mahasiswa kedokteran untuk mendapatkan nilai yang tinggi dapat mengakibatkan adanya sleep disturbance atau gangguan tidur. Gangguan tidur tersebut akan memicu munculnya insomnia, hipersomnia, terganggunya jadwal tidur-jaga (out of synchrony), somnabulisme (sleepwalking), mimpi buruk bahkan teror tidur. ${ }^{5}$

Gangguan tidur didefinisikan sebagai adanya abnormalitas tidur seseorang sehingga mengganggu jumlah, kualitas dan waktu tidur yang biasanya disebabkan oleh hal-hal emosional, sering disebut dengan istilah dyssomnia. Dan juga adanya peristiwa-peristiwa episodik abnormal pada saat tidur yang dikenal dengan istilah parasomnia. Pada kebanyakan kasus, gangguan tidur adalah salah satu dari gangguan lainnya, baik mental maupun fisik. Walaupun gangguan tidur yang spesifik terlihat secara klinis berdiri sendiri, sejumlah faktor fisik dan stresor dapat memberikan kontribusi pada kejadiannya ${ }^{6}$

Stresor yang dihadapi mahasiswa kedokteran tidak hanya menyebabkan mahasiswa rentan stres tetapi juga rentan mengalami gangguan tidur. Gangguan tidur yang dialami pada sebagian mahasiswa adalah insomnia dan hipersomnia, gejala ini sering mengawali adanya kecemasan dan depresi. Hal ini diperkuat oleh hasil penelitian terhadap 1845 mahasiswa yang menyebutkan $27 \%$ setidaknya mengalami satu jenis gangguan tidur dan yang paling sering dialami adalah insomnia dan parasomnia. ${ }^{7}$

Berdasarkan paparan tersebut, dapat diketahui bahwa gangguan tidur akan memberi dampak negatif khususnya pada mahasiswa kedokteran. Secara umum dampak tersebut akan dirasakan oleh mahasiswa kedokteran semester satu dimana mereka harus beradaptasi dengan lingkungan perkuliahan, jadwal kuliah yang padat, tugas kuliah yang berat serta ujian-ujian di akhir blok. Selain mahasiswa semester satu, beban akademik yang berat juga akan dialami oleh mahasiswa kedokteran di semester tujuh yang dibebankan dengan pembuatan skripsi sebagai syarat memperoleh gelar sarjana serta beban menjelang menghadapi tahap profesi dokter (tahap klinik). Beban inilah yang mampu menimbulkan gangguan tidur, dimana menurut Student Health and Welfare menyatakan bahwa jika seseorang mengalami rasa kesal atau terbebani akan suatu hal, maka akan memicu terjadinya kesulitan untuk tidur. ${ }^{8}$

Maka dari itu, penulis tertarik untuk mencari dan mengetahui angka proporsi gangguan tidur pada mahasiswa program studi pendidikan dokter semester satu dan semester tujuh di Fakultas Kedokteran Universitas Udayana.

\section{METODE}

Penelitian ini bersifat kuantitatif menggunakan desain deskriptif dengan pendekatan crossectional untuk mengetahui perbandingan gangguan tidur pada 140 mahasiswa Program Studi Pendidikan Dokter Fakultas Kedokteran Universitas Udayana semester satu dan semester tujuh yang diambil menggunakan stratified random sampling. Variabel penelitian yang diteliti pada studi ini adalah: 1) Jenis kelamin; 2) Usia; dan 3) Gangguan Tidur

Pengumpulan data pada penelitian ini menggunakan beberapa kuisioner pada mahasiswa 
Program Studi Pendidikan Dokter yang telah menjadi subjek penelitian seperti kuisioner untuk menilai kualitas tidur subjek penelitian adalah Pittsburgh Sleep Quality Index (PSQI). Terdapat 10 pertanyaan dalam PSQI. Pertanyaan 1 dan 3 untuk efisiensi kebiasaan tidur, pertanyaan 2 dan 5 a untuk dimensi sleep latensi, pertanyaan 4 untuk dimensi durasi tidur, pertanyaan $5 \mathrm{~b}-5 \mathrm{j}$ untuk dimensi gangguan tidur, pertanyaan 6 untuk dimensi penggunaan obat tidur, pertanyaan 7 dan 8 untuk dimensi disfungsi tidur pada siang hari, pertanyaan 9 untuk dimensi kualitas tidur subjektif dan pertanyaan 10 untuk mengkaji responden memiliki teman tidur. Tiap dimensi nilainya berkisar antara nol (tidak ada masalah) hingga tiga (masalah berat). Nilai tiap komponen kemudian dijumlahkan menjadi skor global antara 0-21. Skor global diatas $5(>5)$

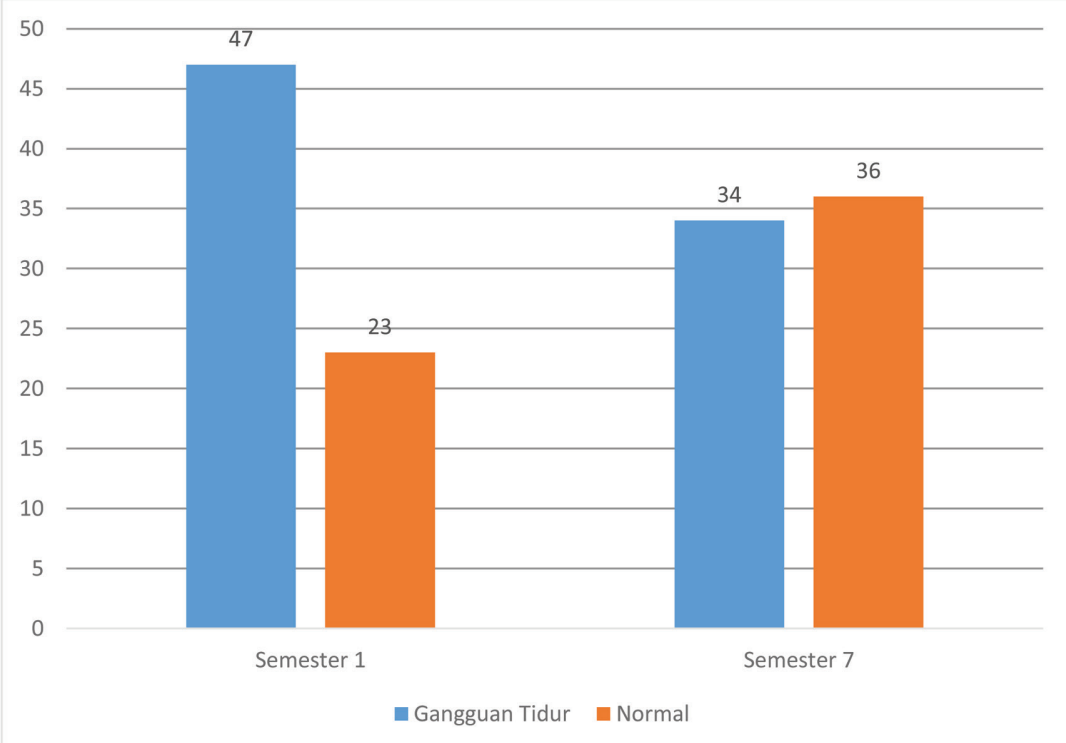

Gambar 1 Sebaran mahasiswa dengan gangguan tidur berdasarkan semester

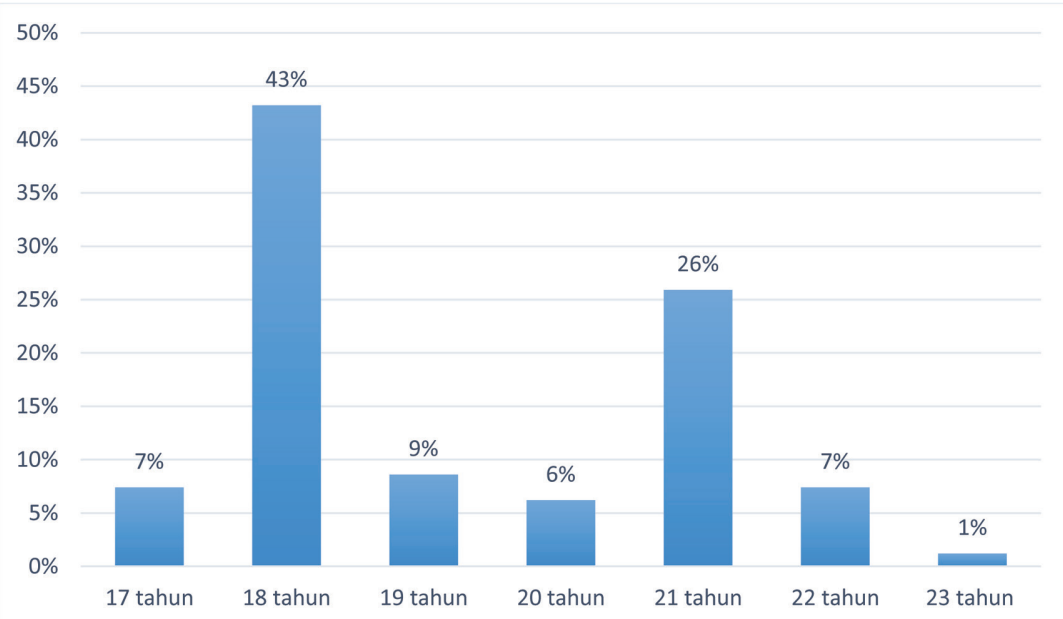

Gambar 2 Gangguan Tidur Pada Mahasiswa PSPD Berdasarkan Umur merupakan responden memiliki gangguan tidur yang signifikan.

Analisis penelitian ini dilakukan secara deskriptif pada program perangkat lunak Statistical Package for Social Science (SPSS) versi 17 dan disajikan dalam bentuk tabel diagram batang.

\section{HASIL PENELITIAN}

Dari total 140 mahasiswa program studi pendidikan dokter yang diambil dari semester satu dan semester tujuh yang memenuhi kriteria inklusi dan eksklusi pada bulan September 2018, didapatkan sebanyak 81 orang $(57,8 \%)$ mengalami gangguan tidur. Adapun sebaran mahasiswa yang mengalami gangguan tidur yang diperoleh dari penelitian ini (Gambar 1).

Pada penelitian ini didapatkan sebanyak 47 orang atau $33,5 \%$ mahasiswa semester satu mengalami gangguan tidur dan hanya 23 orang atau $16,4 \%$ yang tidak mengeluhkan tidur yang terganggu, angka yang lebih rendah muncul pada mahasiswa semester tujuh dimana didapatkan sebanyak 34 orang atau $24,2 \%$ yang mengalami gangguan tidur dan 36 orang atau $25,7 \%$ tidak mengeluhkan gangguan tidur. Berdasarkan nilai tersebut, maka ditemukan proporsi gangguan tidur yang lebih besar pada mahasiswa semester satu dibandingkan dengan mahasiswa semester tujuh.

Data terkait distribusi gangguan tidur pada mahasiswa program pendidikan dokter berdasarkan usia ditunjukkan pada Gambar 2. Data dari 81 orang mahasiswa program studi pendidikan dokter dari semester satu dan semester tujuh, didapatkan rentang usia antara umur 17 tahun hingga 23 tahun yang mengalami gangguan tidur. Adapun distribusi sampel yang diperoleh pada penelitian ini (Gambar 2).

Pada penelitian ini, didapatkan usia 18 tahun memiliki angka gangguan tidur paling banyak yaitu 35 orang atau sebesar $43 \%$, kedua terbanyak pada usia 21 tahun sebanyak 21 orang atau sebesar $26 \%$ dan yang terkecil yaitu pada usia 23 tahun sebesar $1 \%$.

Hasil penelitian menunjukkan bahwa sebanyak 62 orang berjenis kelamin laki-laki dan 78 orang berjenis kelamin perempuan menjadi responden berdasarkan kriteria inklusi dan eksklusi, didapatkan jumlah mahasiswa yang mengalami gangguan tidur. Adapun distribusi sampel yang diperoleh pada penelitian ini (Tabel 1)

Pada penelitian ini, dari 81 orang yang mengalami gangguan tidur, terdapat 32 orang laki-laki (31\%) dan 49 orang perempuan (61\%) yang mengeluhkan tidur yang terganggu. Hasil ini menyatakan bahwa pada mahasiswa kedokteran yang berjenis kelamin 
Tabel 1 Distribusi Gangguan Tidur Pada Mahasiswa PSPD Berdasarkan Jenis Kelamin

\begin{tabular}{lll}
\hline Variabel & N & Gangguan Tidur (\%) \\
\hline Jenis Kelamin & & \\
Laki-laki & 32 & 39,5 \\
Perempuan & 49 & 60,5 \\
\hline
\end{tabular}

perempuan cenderung mengalami gangguan tidur dibandingkan dengan laki-laki.

\section{PEMBAHASAN}

Berdasarkan penelitian yang dilakukan Hanafi tahun 2016 pada 177 orang mahasiswa kedokteran Universitas Andalas, didapatkan angka gangguan tidur sebanyak 142 orang (80\%) pada mahasiswa semester satu dan 35 orang (20\%) pada mahasiswa semester tujuh. ${ }^{9}$ Gangguan tidur yang banyak dikeluhkan adalah terbangun di malam hari sehingga sulit memulai tidur kembali, hal ini diakibatkan karena harus menyelesaikan tugas perkuliahan atau tugas di luar perkuliahan, tugas yang menumpuk menyebabkan ansietas dan mampu meningkatkan kadar norepinefrin oleh saraf simpatis sehingga mengurangi periode tidur stadium IV NREM dan mengganggu kualitas tidur seseorang. Hal ini juga dibuktikan oleh penelitian Riska dan Faisal tahun 2017 pada 160 orang mahasiswa kedokteran Universitas Pajajaran, ditemukan sebanyak 30\% dari mahasiswa semester satu mengalami gangguan tidur sedangkan hanya 15,6\% dari semester tujuh yang mengeluhkan tidur yang terganggu, hal ini diasumsikan akibat seorang mahasiswa sudah jauh dari pengawasan orang tua dan dituntut untuk lebih mandiri dalam melakukan aktivitas hariannya, dalam hal ini pula dijelaskan hubungan dengan adaptasi mahasiswa semester satu dengan dunia perkuliahan. ${ }^{10}$

Berdasarkan penelitian Abdelkader dkk pada tahun 2018 terhadap 600 mahasiswa fakultas kedokteran di negara Maroko, didapatkan angka gangguan tidur terbesar yaitu pada usia 21 tahun dengan jumlah sebanyak 190 orang dan yang paling rendah adalah pada usia 20 tahun yaitu sebanyak 76 orang. ${ }^{11}$ Pada penelitian lain yang dilakukan di Indonesia oleh Rika dkk pada tahun 2015 mendapatkan hasil gangguan tidur pada mahasiswa fakultas kedokteran di Riau terbanyak pada rentang usia 18 hingga 20 tahun yaitu sebanyak 81 orang dan pada rentang 21-23 hanya sebanyak 19 orang, dimana pada usia 18 tahun diasumsikan sebagai masa peralihan dari remaja ke dewasa muda dimana terjadi perubahan diantaranya kebutuhan beradaptasi dengan perubahan lingkungan sosial, pencarian identitas dan membentuk hubungan baru, perubahan-perubahan ini dapat menimbulkan stres yang kemudian dapat menghasilkan kualitas tidur yang terganggu. ${ }^{12}$

Penelitian yang dilakukan oleh Shad R dkk yang meneliti 214 mahasiswa kedokteran, ditemukan sebanyak 133 orang mahasiswa mengalami gangguan tidur dengan persentase perempuan yang lebih dominan mengalami gangguan tidur sebesar $65,8 \%$ dibandingkan dengan pria yaitu $34 \%{ }^{13}$ Penelitian lain yang dilakukan Mustafa tahun 2016 di salah satu fakultas kedokteran di negara Turki meneliti 412 orang mahasiswa kedokteran, sebanyak $34,5 \%$ mengalami gangguan tidur dan didapatkan bahwa mahasiswa berjenis kelamin perempuan mengalami gangguan tidur (22\%) lebih banyak dari mahasiswa berjenis kelamin laki-laki (12\%). ${ }^{14}$ Hal ini diasumsikan karena mahasiswi kedokteran di negara tersebut memiliki kecenderungan akan bersaing secara akademik lebih tinggi dibandingkan mahasiswa kedokteran. Dari penelitian yang dilakukan oleh Nashori pada tahun 2015 di Universitas Islam Indonesia yang menggunakan sampel sebanyak 319 orang, dari banyaknya sampel yang mengalami gangguan tidur, $69,3 \%$ merupakan mahasiswi sedangkan pada mahasiswa sebesar $27,9 \%$. Hal ini diasumsikan pula sebagai akibat dari tingginya keinginan bersaing secara akademik yang lebih tinggi dari mahasiswa berjenis kelamin laki-laki.

\section{SIMPULAN}

Proporsi gangguan tidur berdasarkan semester didapatkan angka gangguan tidur yang lebih banyak terjadi pada mahasiswa semester satu dibandingkan dengan semester tujuh, diikuti dengan usia 18 tahun memiliki angka gangguan tidur paling banyak. Berdasarkan jenis kelamin, proporsi gangguan tidur didapatkan sebagian besar berjenis kelamin perempuan. Terdapat beberapa faktor resiko penyebab terjadinya gangguan tidur seperti tingkat stres,cemas dan adaptasi mahasiswa terhadap lingkungan belajar perkuliahan sehingga untuk penelitian selanjutnya disarankan untuk mencari hubungan antara gangguan tidur dengan beberapa faktor resiko tersebut.

\section{ETIKA PENELITIAN}

Studi ini telah mendapat persetujuan etik dari komisi etik Fakultas Kedokteran Universitas Udayana, Bali, Indonesia sebelum penelitian dilakukan 


\section{KONFLIK KEPENTINGAN}

Tidak terdapat konflik kepentingan dalam penulisan laporan penelitian untuk publikasi ini.

\section{PENDANAAN}

Penulis bertanggung jawab terhadap pendanaan penelitian ini tanpa keterlibatan dari pihak manapun.

\section{KONTRIBUSI PENULIS}

I Nyoman Andika Kumara bertanggung jawab terhadap pembuatan usulan penelitian, pencarian data, analisis data, hingga pembuatan laporan penelitian. Luh Nyoman Alit Aryani dan Ni Ketut Sri Diniari bertanggung jawab dalam penyempurnaan laporan penelitian.

\section{DAFTAR PUSTAKA}

1. Bertens D, Fasotti L, Boelen DH, Kessels RP. A randomized controlled trial on errorless learning in goalmanagement training: study rationale and protocol. BMC Neurol. 2013; 13:64

2. Wardhana CA. Prevalensi Cemas Pada Mahasiswa Kedokteran Yang Mengikuti Uji Kompetensi Mahasiswa Program Profesi Dokter di Fakultas Kedokteran Universitas Udayana. Bagian Ilmu Kesehatan Jiwa Fakultas Kedokteran Universitas Udayana. E-Jurnal Medika Udayana. 2015; 4(3):1-12

3. Lubis \& Nurlaila. Mengapa Tingkat Stres Pelajar Makin Tinggi?. Style Sheet. Viva News. 2010. [Tersedia pada: www. vivanews.com/news/read/120642-mengapa_tingkat_ stres_pelajar_makin_tinggi ]. [Diakses pada tanggal 17 September 2018].

4. Robotham D. Stres Among Higher Education Students: Towards a Research Agenda. High Educ. 2008; 56:735-746.

5. Seo JH, Kim HJ, Kim BJ, Lee SJ, Bae HO. Educational and Relational Stressors Associated with Burnout in Korean Medical Students. Psychiatry Investig. 2015; 12(4):451-8.
6. Kaplan, Sadock. Synopsis of Psychiatry. Sadock BJ, Sadock VA, Ruiz Pedro, editors. New York: Lippincot Williams \& Wilkins Medical Books. Wolters Kluwer Copyright (c). 11th ed. 2015

7. Gaultney JF. The prevalence of sleep disorders in college students: impact on academic performance. J Am Coll Health. 2010; 59(2):91-7

8. Ulfah FH. Hubungan Insomnia Dengan Tingkat Stres Pada Mahasiswi Tingkat Akhir Program Studi S1 Fisioterapi Universitas Muhammadiyah Surakarta. Fakultas Ilmu Kesehatan Universitas Muhammadiyah Surakarta. [Skripsi]. 2014

9. Hanafi. Hubungan Kualitas Tidur dengan Prestasi Akademik Mahasiswa Program Studi Pendidikan Dokter Angkatan 2010 FK Universitas Andalas. Jurnal Kesehatan Andalas. 2016; 5(1):243-249.

10. Riska, Faisal. Perbandingan Kualitas Tidur Mahasiswa Fakultas Kedokteran Universitas Padjajaran Yang Menggunakan Dan Tidak Menggunakan Cahaya Lampu. JSK. 2017; 3(2):73-79.

11. El Hangouche AJ, Jniene A, Aboudrar S, et al. Relationship between poor quality sleep, excessive daytime sleepiness and low academic performance in medical students. Adv Med Educ Pract. 2018; 9:631-638.

12. Rika et al. Hubungan Kualitas Tidur Dengan Tekanan Darah Dan Konsentrasi Belajar Mahasiswa Program Studi Ilmu Keperawatan Universitas Riau. JOM. 2015; 2(2): 1435-1443.

13. Shad R, Thawani R, Goel A. Burnout and Sleep Quality: A Cross-Sectional Questionnaire-Based Study of Medical and Non-Medical Students in India . Cureus. 2015; 7(10): $1-10$.

14. Saygin M, Öztürk Ö, Gonca T, et al. Investigation of Sleep Quality and Sleep Disorders in Students of Medicine. Turk Thorac J. 2016; 17(4): 132-140.

15. Nashori F, Diana RR. Perbedaan Kualitas Tidur dan Kualitas Mimpi Antara Mahasiswa Laki-laki dan Mahasiswa Perempuan. Indonesian Physiological Journal. 2015; 2(2): 77-88.

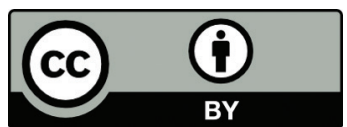

This work is licensed under a Creative Commons Attribution 